\title{
Variability in the Structure of Phytoplankton Assemblages in relation to Human Disturbance in Southern Coast of Tunisia
}

\author{
Lotfi Mabrouk, ${ }^{1,2}$ Lamia Dammak, ${ }^{2}$ Asma Hamza, ${ }^{2}$ \\ Mabrouka Mahfoudhi, ${ }^{2}$ and Med-Najmeddine Bradai ${ }^{2}$ \\ ${ }^{1}$ Faculty of Sciences of Sfax, Sfax University, Soukra Street km 4, BP 802, 3038 Sfax, Tunisia \\ ${ }^{2}$ National Institute of Sciences and Technologies of the Sea, Center of Sfax, BP 1035, 3018 Sfax, Tunisia \\ Correspondence should be addressed to Lotfi Mabrouk; lotfi2328@yahoo.fr
}

Received 23 February 2014; Revised 29 May 2014; Accepted 2 June 2014; Published 25 June 2014

Academic Editor: Robert A. Patzner

Copyright (C) 2014 Lotfi Mabrouk et al. This is an open access article distributed under the Creative Commons Attribution License, which permits unrestricted use, distribution, and reproduction in any medium, provided the original work is properly cited.

\begin{abstract}
We investigated the impact of industrial effluents on phytoplankton assemblage in southern Tunisia (Skhira). We specifically addressed changes in microalgae composition caused by this anthropogenic interference. A hierarchical sampling design was used to compare planktonic microalgae structure between one disturbed station and one control station. Samples were collected by scuba diving at $5 \mathrm{~m}$ depth in August 2012. A total of 76 microalgae taxa were identified. Dinoflagellates abundance was low in the disturbed station, especially Gonyaulacales and Prorocentrales due to P-limitation, whereas diatoms and cyanobacteria abundance were low in control station which is characterized by Si-limitation.
\end{abstract}

\section{Introduction}

Marine ecosystems are particularly vulnerable to environmental change and many are, at present, severely degraded [1]. The availability of good quality water is an indispensable feature for preserving biodiversity. In recent years, increase in human population and industrial activity have led to faster degradation of many coastal ecosystems. The discharge of urban, industrial, and agricultural wastes has added the quantum of various harmful chemicals to the water body considerably altering their inherent physicochemical characteristics [2].

Phytoplankton constitutes the basic components of the aquatic food chain. They act as primary producers and represent themselves as a direct food source for other aquatic animals [3]. Quantifying the phytoplankton community composition is essential for understanding the structure and the dynamics of marine ecosystems [4]. It is also important to evaluate the role of the physical and chemical processes on the biological responses of the ecosystem. The interplay of physical, chemical, and biological properties of water most often leads to the production of phytoplankton, while their assemblage (composition, distribution, diversity, and abundance) is also structured by these factors.
It is, therefore, of importance to undertake a study of the effects of urban and industrial pressure on phytoplankton dynamics under the impact of human activities versus control conditions. In southern Tunisia, we analyzed the phytoplankton diversity and abundance and asked if anthropogenic disturbance such as industrial effluents causes their variations.

We attempted to answer the following question: how nutrient enrichment induced by anthropogenic disturbance affects abundance and species composition of phytoplankton community? We thus compared phytoplankton assemblages between a station exposed to industrial effluents and a control station and examined their variability at spatial scales using a hierarchical sampling design [5].

\section{Materials and Methods}

2.1. Study Area. The study was carried out in two sampling stations (Figure 1), $100 \mathrm{~km}$ apart, were chosen in August 2012; unpolluted station in the east of Tunisia, Mahdia (M) $\left(35^{\circ} 35^{\prime} 43^{\prime \prime} \mathrm{N} 11^{\circ} 05^{\prime} 42^{\prime \prime} \mathrm{E}\right)$, was selected as control station, and Skhira (K) $\left(34^{\circ} 19^{\prime} .179^{\prime} \mathrm{N} 10^{\circ} 11^{\prime} .706^{\prime \prime} \mathrm{E}\right)$ was chosen as disturbed station, localised in the Gulf of Gabes. This station 


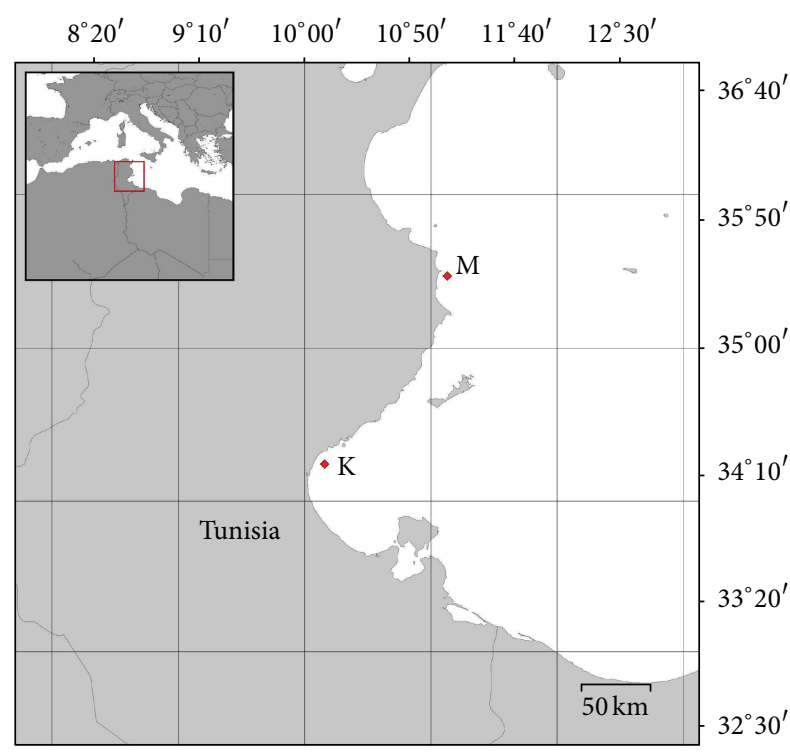

FIGURE 1: Map of the study area, showing the sampling stations with M, Mahdia (control station), and K, Skhira (disturbed station).

is exposed, since 1988, to industrial effluents from phosphoric acid and fertilizer production of the "Groupe Chimique Tunisien" (GCT). These industrial activities affect this marine ecosystem [6] as in deterioration of seagrass bed $[7,8]$ and decline in fishing [9]. The sampling depth in all stations was $5 \mathrm{~m}$.

2.2. Sampling and Data Collection. In accordance with the hierarchical sampling design, three sites (500 m apart) were chosen randomly at each station. At each site, three replicate water samples were collected from each site for nutrient analyses. Samples were taken using a $125 \mathrm{~mL}$ plastic bottle, having received prior treatment with hydrochloric acid. On returning to the surface, samples were shaken and then filtered with a $0.45 \mu \mathrm{m}$ filter (cellulose acetate, $17 \mathrm{~mm}$ ). Samples were frozen in liquid nitrogen for transportation to the laboratory, where concentrations of $\mathrm{NO}_{2}{ }^{-}, \mathrm{NO}_{3}{ }^{-}$, $\mathrm{NH}_{4}{ }^{+}, \mathrm{PO}_{4}{ }^{-}, \mathrm{Si}(\mathrm{OH})_{4}$, total dissolved nitrogen (TN), and total dissolved phosphorus (TP) were measured following standard colorimetric techniques [10].

In each site, temperature, salinity, and $\mathrm{pH}$ were measured immediately after sampling using a multiparameter kit (Multi 340i/SET). For determination of suspended particulate matter (SM) concentration, water samples were filtered through preweighed GF/C Whatman filters (pore size $0.45 \mathrm{pm}$ ), which were subsequently dried at $80^{\circ} \mathrm{C}$ for about $24 \mathrm{~h}$ and reweighed [11].

For phytoplankton enumeration, three replicate water samples (about $100 \mathrm{~m}$ apart at $5 \mathrm{~m}$ depth) were selected from the same sites. Water column samples, using 1-litre glass bottle sampler lowered from the surface to the near bottom, were conducted by scuba diving. All samples were collected at noon.

Samples were fixed with Lugol's solution and finally preserved in $5 \%$ formalin. All sampling waters were kept in the dark at ambient temperature until their microscopic observation. Settling long glass tubes used for sedimentation procedure were $2 \mathrm{~cm}$ wide by $21 \mathrm{~cm}$ long and have a base plate that contains a coverslip on which the algae settle. To mix the sample, the bottle was gently tilted back and forth 10 times before pouring [12]. A $50 \mathrm{~mL}$ subsample was poured into the settling chamber and left to settle for $24 \mathrm{~h}$. subsamples were examined in an inverted microscope at medium $(\times 200)$ magnification by scanning the entire surface of the settling chamber to enumerate epiphytic microalgae $[12,13]$. The total number of microalgae individuals $(N)$ contained in 1 litre expressed as number of individuals per litre is obtained by the following conversion: $N=(n \times 1000) /(v)$, with $n$ $=$ the number of individuals counted and $v=$ the volume of the sedimentation chamber $(50 \mathrm{~mL})$ [13]. The identified taxa were divided into groups (diatoms, dinoflagellates, and cyanobacteria).

2.3. Data Analysis. Data were tested for normality using the Kolmogorov-Smirnov test [14] and for heteroscedasticity using Cochran's $C$ test and transformed if necessary [5].

Relationships between species abundance and abiotic parameters were examined using the RELATE procedure in PRIMER. RELATE is the equivalent of a nonparametric Mantel test [15]; it assesses the degree of correspondence between matrices, and, via a randomization test, it provides a measure of statistical significance of the relationship [16]: the matrix of similarities between phytoplankton species abundances (based on Bray-Curtis coefficient from $\log (x+$ 1)-transformed data) was compared with a matrix of the similarity between abiotic parameters (based on Euclidean distance from $\log (x+1)$-transformed data). The significance of any correlation between matrices is assessed with a randomization test.

Analyses of similarity (ANOSIM) randomization tests were used to test for differences in community composition (with presence/absence transformed data) and for differences in species abundance (with $\log (x+1)$-transformed data) between control and disturbed stations [17]. Differences found using ANOSIM were followed up using the SIMPER analysis to identify which species primarily accounted for the observed differences between sites. SIMPER generates a ranking of the species responsible for the significant differences. These analyses used a matrix composed of Bray-Curtis similarity coefficient generated with $\log (x+1)$-transformed species abundance data [13].

Analysis of variance (ANOVA) was used to test the hypothesis that the abundance of each group of taxa differed between disturbed and control stations [13]. Factor station was fixed. The same design was employed for nutrient concentrations, $\mathrm{pH}$, temperature, and suspended matter. Tukey's HSD test was applied for multiple comparisons of means.

Canonical correspondence analysis (CCA), a direct gradient analysis technique [18], was used to investigate the relationship between microalgae species and environmental parameters. Microalgae abundance data were $\log (x+1)$ transformed prior to the analysis in order to stabilise the variance and to optimise the signal-to-noise ratio in the 
TABLE 1: The mean \pm SD values of physical and chemical variables measured at all stations during the sampling period. Difference between control station $(\mathrm{M})$ and disturbed station $(\mathrm{K})$ was tested by ANOVA.

\begin{tabular}{|c|c|c|c|c|c|c|}
\hline Variables & Unit & $N$ & Disturbed station $(\mathrm{K})$ & Control station $(\mathrm{M})$ & $F_{(1,16)}$ & Tukey's test \\
\hline SM & $\mathrm{g} \cdot \mathrm{L}^{-1}$ & 9 & $12.00 \pm 6.76$ & $7.00 \pm 0.70$ & 4.32 & n.s. \\
\hline $\mathrm{NO}_{2}^{-}$ & $\mu \mathrm{mol} \cdot \mathrm{L}^{-1}$ & 9 & $0.301 \pm 0.12$ & $0.283 \pm 0.09$ & 0.119 & n.s. \\
\hline $\mathrm{NO}_{3}^{-}$ & $\mu \mathrm{mol} \cdot \mathrm{L}^{-1}$ & 9 & $4.91 \pm 2.85$ & $5.91 \pm 0.04$ & 0.98 & n.s. \\
\hline $\mathrm{NH}_{4}^{+}$ & $\mu \mathrm{mol} \cdot \mathrm{L}^{-1}$ & 9 & $23.36 \pm 16.80$ & $4.17 \pm 0.19$ & $10.42^{*}$ & $\mathrm{M}<\mathrm{K}$ \\
\hline $\mathrm{PO}_{4}{ }^{3-}$ & $\mu \mathrm{mol} \cdot \mathrm{L}^{-1}$ & 9 & $0.307 \pm 0.17$ & $0.684 \pm 0.05$ & $25.33^{* * *}$ & $\mathrm{~K}<\mathrm{M}$ \\
\hline $\mathrm{Si}(\mathrm{OH})_{4}$ & $\mu \mathrm{mol} \cdot \mathrm{L}^{-1}$ & 9 & $8.28 \pm 1.93$ & $0.94 \pm 0.05$ & $115.41^{* * *}$ & $\mathrm{M}<\mathrm{K}$ \\
\hline $\mathrm{TP}$ & $\mu \mathrm{mol} \cdot \mathrm{L}^{-1}$ & 9 & $3.26 \pm 0.84$ & $3.34 \pm 0.34$ & $9.86^{*}$ & $\mathrm{M}<\mathrm{K}$ \\
\hline $\mathrm{TN}$ & $\mu \mathrm{mol} \cdot \mathrm{L}^{-1}$ & 9 & $45.29 \pm 26.08$ & $16.32 \pm 0.47$ & $9.86^{*}$ & $\mathrm{M}<\mathrm{K}$ \\
\hline $\mathrm{pH}$ & & 9 & $7.97 \pm 0.15$ & $7.32 \pm 0.34$ & $25.70^{* * *}$ & $\mathrm{M}<\mathrm{K}$ \\
\hline Salinity & $g \cdot L^{-1}$ & 9 & $38.91 \pm 0.44$ & $38.24 \pm 0.88$ & 3.96 & n.s. \\
\hline$T^{\circ}$ & ${ }^{\circ} \mathrm{C}$ & 9 & $31.03 \pm 1.05$ & $27.26 \pm 0.96$ & $59.02^{*}$ & $\mathrm{M}<\mathrm{K}$ \\
\hline
\end{tabular}

${ }^{*} P<0.05 ;{ }^{* * *} P<0.001$; SM: suspended matter; n.s.: not significant.

data set. Downweighting for rare species was performed. Forward selection and associated Monte Carlo permutation tests (499 unrestricted permutations) were used to identify a subset of environmental variables that contributed mostly to the species abundances in the data set. The environmental parameters which better described the distribution of the species data were a priori identified by forward selection [18]. Only significant environmental variables are included in the model. The same procedure was repeated using species abundance and nutrient ratios $(\mathrm{Si}: \mathrm{N}, \mathrm{N}: \mathrm{P}$, and $\mathrm{Si}: \mathrm{P})$. CANOCO 4.5 (Scientia Software) software was used.

\section{Results}

The disturbed station $(\mathrm{K})$ exhibited quite higher concentrations of ammonium, $\mathrm{Si}(\mathrm{OH})_{4}$, TP, and $\mathrm{TN}$ and higher $\mathrm{pH}$ and temperature. Phosphate was higher in control station (M) (Table 1). We also calculate nutrient ratios; N/P ratio [DIN $\left(\mathrm{DIN}=\mathrm{NO}_{2}{ }^{-}+\mathrm{NO}_{3}{ }^{-}+\mathrm{NH}_{4}{ }^{+}\right)$to DIP $\left.\left(\mathrm{DIP}=\mathrm{PO}_{4}{ }^{3-}\right)\right]$ in disturbed station $(\mathrm{K})$ was $75.73 \pm 35.43$ (mean \pm sd) and $15.24 \pm 1.22$ in control station $(\mathrm{M})$. This average in disturbed station was higher than the Redfield ratio (16), which suggests potential P-limitation in this station. $\mathrm{Si} / \mathrm{N}$ ratio was $0.41 \pm 0.20$ and $0.09 \pm 0.01$ in disturbed and control stations, respectively. $\mathrm{Si} / \mathrm{P}$ ratio was $26.38 \pm 9.99$ and $1.39 \pm 0.14$ in disturbed station and control station, respectively, which suggests potential Silimitation in control station.

The results of RELATE tests indicated that there is a correlation between physicochemical parameters and species abundance (Spearman rank correlation statistic, Rho = 0.484 ). None of the 999 random permutations resulted in a correlation equal to or greater than the measured value of 0.484 , indicating that the correlation was significant at the $P<0.001$ level.

For phytoplankton, 76 species were counted including 54 in the control station $(\mathrm{M})$ and 74 species in the disturbed station (K) (Table 2). Analysis of similarity (ANOSIM) of phytoplankton microalgae species abundances $\log (x+1)$ transformed showed significant differences $(R=0.954$; $P=0.01)$ between the control station and the disturbed

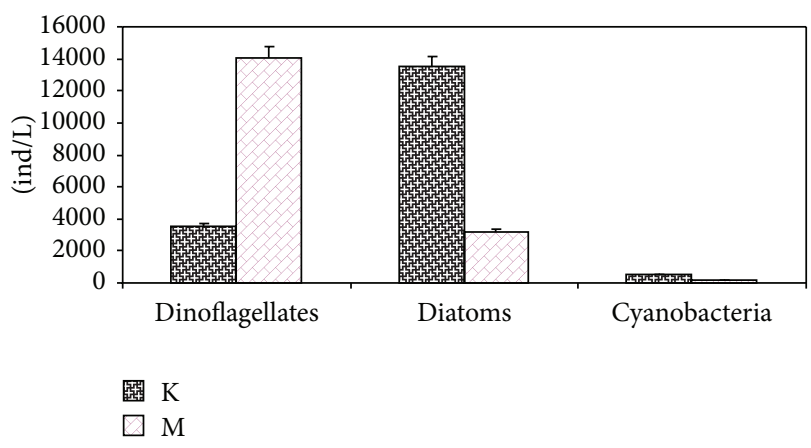

Figure 2: Average abundance of planktonic microalgae in prospected stations, K: Skhira (disturbed station), M: Mahdia (control station).

station. Similar results are obtained $(R=0.913 ; P=0.01)$ using presence/absence transformed data showing that the dissimilarities between stations are due to both species composition and their abundances.

Dinoflagellates, diatoms, and cyanobacteria were common in water column (Figure 2). Abundances of those groups were included in the univariate analyses of variance. The number of species $(S)$ was higher in polluted station $\left(F_{(1 ; 17)}\right.$ $=6.95, P=0.017)$. Dinoflagellates differed significantly between stations $\left(F_{(1 ; 17)}=5.66, P=0.029\right)$ with high abundance in control station (Tukey's test). When dinoflagellates were grouped in order, significant differences were detected for Prorocentrales and Gonyaulacales $\left(F_{(1 ; 17)}=6.17, P=\right.$ 0.024 and $F_{(1 ; 17)}=12.49, P=0.003$, resp.) which were more abundant in control station. Diatoms abundance was higher $\left(F_{(1 ; 17)}=16.39, P<0.001\right)$ in disturbed station $(K)$ and specially centric diatoms $\left(F_{(1 ; 17)}=7.16, P=0.016\right)$. Cyanobacteria abundance was also higher $\left(F_{(1 ; 17)}=12.61\right.$, $P=0.002)$ in disturbed station $(K)$. No significant differences were recorded for total abundance and for $H^{\prime}$ index.

Analyses of similarity percentage (SIMPER) showed that the average dissimilarity between the control and disturbed groups is high $(86.31 \%)$. This procedure also allowed determining the species that contribute to this dissimilarity; 
TABLE 2: Presence-absence species list of planktonic microalgae identified in prospected stations.

\begin{tabular}{|c|c|c|}
\hline & \multicolumn{2}{|c|}{ Stations } \\
\hline & $\begin{array}{c}\text { Skhira (K) } \\
\text { (disturbed station) }\end{array}$ & $\begin{array}{c}\text { Mahdia }(\mathrm{M}) \\
\text { (control station) }\end{array}$ \\
\hline \multicolumn{3}{|l|}{ Dinoflagellates } \\
\hline Alexandrium minutum Halim & 1 & 1 \\
\hline Alexandrium sp. & 1 & 1 \\
\hline Amphidinium carterae Hulburt & 1 & 1 \\
\hline Amphidinium sp. & 1 & 1 \\
\hline Ceratium candelabrum (Ehrenberg) Stein & 1 & 0 \\
\hline Ceratium furca (Ehrenberg) Claparède \& Lachmann & 1 & 1 \\
\hline Ceratium fusus (Ehrenberg) Dujardin & 1 & 0 \\
\hline Ceratium lineatum (Ehrenberg) Cleve & 1 & 0 \\
\hline Coolia monotis Meunier & 1 & 1 \\
\hline Dinophysis rotundata Claparède \& Lachmann & 1 & 0 \\
\hline Diplopsalopsis sp. & 1 & 1 \\
\hline Goniodoma polyedricum (Pouchet) Jørgensen & 1 & 1 \\
\hline Gonyaulax polyedra F.Stein & 1 & 1 \\
\hline Gonyaulax sp. & 1 & 1 \\
\hline Gonyaulax spinifera (Claparède \& Lachmann) Diesing & 1 & 1 \\
\hline Gymnodinium veneficum & 1 & 0 \\
\hline Gyrodinium sp. & 1 & 1 \\
\hline Hermesinum sp. & 1 & 1 \\
\hline Karenia selliformis A.J.Haywood, K.A.Steidinger \& L.MacKenzie in Haywood et al. & 1 & 0 \\
\hline karlodinium veneficum & 1 & 1 \\
\hline Ostreopsis ovata Fukuyo & 1 & 1 \\
\hline Peridinium sp. & 1 & 1 \\
\hline Podolampas palmipes Stein & 1 & 1 \\
\hline Polykrikos sp. & 1 & 1 \\
\hline Prorocentrum gracile Schütt & 1 & 1 \\
\hline Prorocentrum lima (Ehrenberg) Dodge & 1 & 1 \\
\hline Prorocentrum micans Ehrenberg & 0 & 1 \\
\hline Prorocentrum minimum (Pavillard) Schiller & 1 & 1 \\
\hline Prorocentrum rathymum (Loeblich) Shirley and Schmidt & 1 & 1 \\
\hline Prorocentrum triestinum J.Schiller & 1 & 1 \\
\hline Protoperidinium divergens (Ehrenberg) Balech & 1 & 1 \\
\hline Protoperidinium granii (Ostenfeld) Balech & 1 & 1 \\
\hline Protoperidinium ovatum Pouchet & 1 & 1 \\
\hline Protoperidinium pellucidum Bergh ex Loeblich Jr. \& Loeblich III & 1 & 0 \\
\hline Protoperidinium quinquecorne (Abé) Balech & 1 & 1 \\
\hline Protoperidinium sp. & 1 & 1 \\
\hline Protoperidinium steinii (Jørgensen) Balech & 1 & 1 \\
\hline Protoperidinium diabolus (Cleve) Balech & 1 & 0 \\
\hline Pyrophacus sp. & 1 & 0 \\
\hline Scrippsiella sp. & 1 & 1 \\
\hline \multicolumn{3}{|l|}{ Diatoms } \\
\hline Achnanthes sp. & 1 & 0 \\
\hline Amphiprora sp. & 1 & 0 \\
\hline Amphora sp. & 1 & 1 \\
\hline
\end{tabular}


TABLE 2: Continued.

\begin{tabular}{|c|c|c|}
\hline & & \\
\hline & $\begin{array}{c}\text { Skhira }(\mathrm{K}) \\
\text { (disturbed station) }\end{array}$ & $\begin{array}{c}\text { Mahdia (M) } \\
\text { (control station) }\end{array}$ \\
\hline Asterionellopsis glacialis (Castracane) Round & 1 & 0 \\
\hline Bacteriastrum sp. & 1 & 1 \\
\hline Biddulphia sp. & 1 & 1 \\
\hline Bacteriosira fragilis (Gran) Gran & 0 & 0 \\
\hline Coscinodiscus sp. & 1 & 0 \\
\hline Chaetoceros sp. & 1 & 1 \\
\hline Climacosphenia sp. & 1 & 1 \\
\hline Guinardia sp. & 1 & 1 \\
\hline Grammatophora sp. & 1 & 1 \\
\hline Licmophora sp. & 1 & 1 \\
\hline Leptocylindrus sp. & 1 & 1 \\
\hline Melosira sp. & 1 & 1 \\
\hline Navicula sp. & 1 & 1 \\
\hline Nitzschia sp. & 1 & 1 \\
\hline Nitzshoides sp. & 1 & 0 \\
\hline Plagiotropis sp. & 1 & 1 \\
\hline Pseudo-nitzschia sp. & 1 & 0 \\
\hline Pinnularia sp. & 1 & 1 \\
\hline Pleurosigma sp. & 1 & 1 \\
\hline Rhizosolenia sp. & 1 & 1 \\
\hline Rhizosolenia fragilissima Bergon & 1 & 1 \\
\hline Rhabdonema sp. & 1 & 1 \\
\hline Striatella unipunctata (Lyngbye) C.Agardh & 1 & 0 \\
\hline Skeletonema costatum (Greville) Cleve & 1 & 0 \\
\hline Thalassionema nitzschioides (Grunow) Mereschkowsky & 1 & 1 \\
\hline Thalassiosira sp. & 1 & 0 \\
\hline Synedra sp. & 1 & 1 \\
\hline Triceratium sp. & 1 & 0 \\
\hline & & \\
\hline Anabaena sp. & 1 & 1 \\
\hline Pseudo-anabaena sp. & 1 & 0 \\
\hline Oscillatoria sp. & 1 & 1 \\
\hline Spirulina subsalsa Oersted ex Gomont & 1 & 0 \\
\hline Croccocus sp. & 1 & 0 \\
\hline
\end{tabular}

they are Coscinodiscus sp., Nitzshoides sp., Chaetoceros sp., Anabaena sp., Gyrodinium sp., Biddulphia sp., Striatella unipunctata, Thalassiosira sp., Leptocylindrus sp., and Scrippsiella sp. Species which were more abundant in disturbed station (K) are Biddulphia sp., Polykrikos sp., Pleurosigma sp., Coolia monotis, and Amphidinium carterae (Table 4). Species which had higher abundance in control station are Ostreopsis ovata, Coolia monotis, Prorocentrum lima, Pleurosigma sp., Peridinium sp., Pinnularia sp., and Polykrikos sp.

CCA analysis using all measured physicochemical parameters (Table 5) indicated that the axis I (eigenvalue $\lambda_{1}=0.493$ ) and axis II (eigenvalue $\lambda_{2}=0.154$ ) expressed $47.5 \%$ of the cumulative variance species-environmental variable. Eigenvalues ( $P$ value) calculated with the CCA associated with the analysis in Monte Carlo test were used to select four environmental variables statistically significant $(P<0.05)$ that explain better variations $(81.88 \%)$ of species composition: they are $\mathrm{Si}(\mathrm{OH})_{4}, \mathrm{NH}_{4}{ }^{+}, \mathrm{TN}$, and suspended matter $(33.72 \%, 9.41 \%, 10.18 \%$, and $11.86 \%$ of total variance, resp.). In the triplot diagram (Figure 3 ) disturbed station samples $(\mathrm{K})$ were grouped in the right and are correlated with the axis $\mathrm{I}$, which is defined by the environmental 


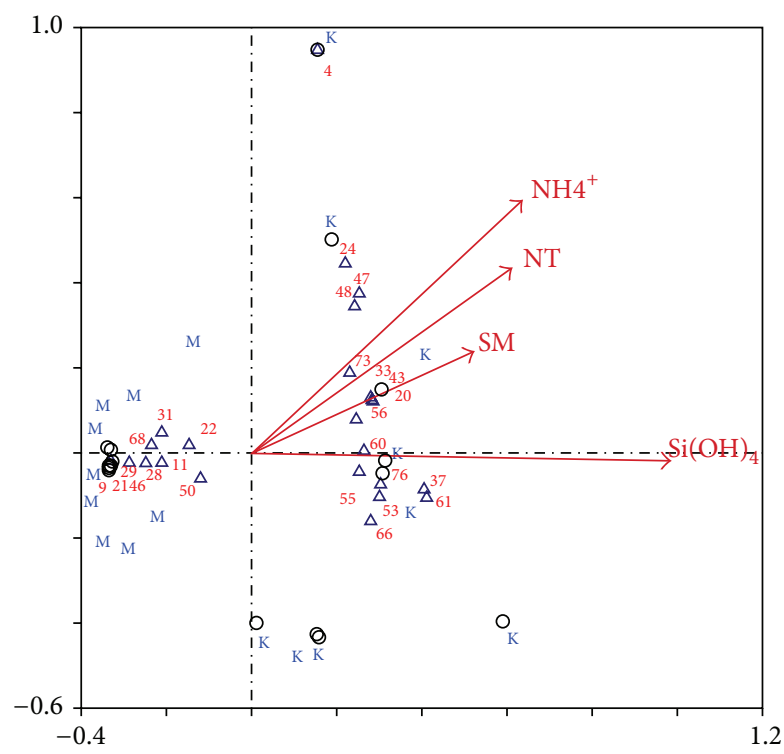

FIGURE 3: Diagram of canonical correspondence analysis (CCA) showing the effects of environmental variables on microalgae species ordination according to the first and second axes. Species associated with $\mathrm{K}$ (disturbed station) samples are as follows: 4: Amphidinium sp., 24: Prorocentrum minimum, 48: Achnanthes sp., 20: Karenia selliformis, 56: Chaetoceros sp., 60: Licmophora sp., 76: Thalassiosira sp., 55: Coscinodiscus sp., 53: Biddulphia sp., 37: Protoperidinium pellucidum, 61: Leptocylindrus sp., and 66: Plagiotropis sp. Species associated with $M$ (control station) samples are as follows: 9: Coolia monotis, 11: Diplopsalopsis sp., 21: Ostreopsis ovata, 22: Peridinium sp., 28: Prorocentrum lima, 29: Prorocentrum triestinum, 50: Amphora sp., and 68: Pinnularia sp. Species whose coverage and frequency are less than $40 \%$ were eliminated.

variables $\mathrm{Si}(\mathrm{OH})_{4}, \mathrm{NH}_{4}{ }^{+}, \mathrm{TN}$, and suspended matter (intraset correlation $-0.955,-0.613,-0.588$, and -0.497 , resp.).

CCA analysis using nutrients' ratios (Table 5) indicated that axis I (eigenvalue $\lambda_{1}=0.153$ ) and axis II (eigenvalue $\lambda_{2}=0.104$ ) expressed $45.20 \%$ of the cumulative variance species-environmental variable. Monte Carlo test showed that all nutrient ratios were statistically significant $(P=$ 0.002 ) and explain $45.22 \%$ of variation of species ordination detailed as Si : P (55.04\%), N : P (24.65\%), and Si : P (20.3\%) of total explained variance. In the triplot diagram (Figure 4) disturbed station samples $(\mathrm{K})$ were grouped in the right and are correlated with axis I, which is defined by the nutrient ratios $\mathrm{N}: \mathrm{P}, \mathrm{Si}: \mathrm{N}$, and $\mathrm{Si}: \mathrm{P}$ (intraset correlation $0.720,-0.761$, and 0.877 , resp.). Most of diatoms species were associated with $\mathrm{K}$ samples (disturbed station), while $\mathrm{M}$ samples (control station) were associated with dinoflagellates species (Figure 4).

\section{Discussion}

Our results show that the abundance and composition of phytoplankton varied between the disturbed and control stations. Dinoflagellates abundance, especially the orders Prorocentrales and Gonyaulacales, was low in disturbed

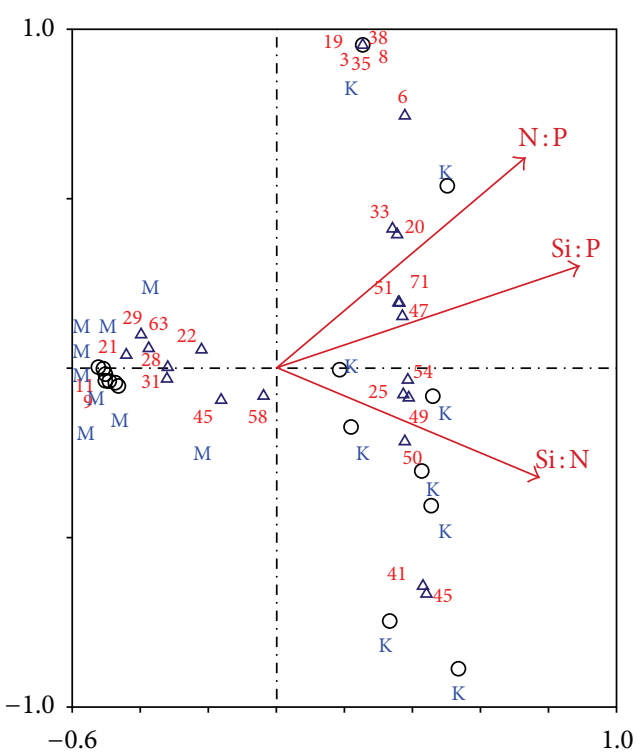

FIGURE 4: Diagram of canonical correspondence analysis (CCA) showing the effects of nutrient ratios on microalgae species ordination according to the first and second axes. Species associated with $\mathrm{K}$ (disturbed station) were the dinoflagellates 3: Amphidinium carterae, 19: Karlodinium veneficum, 8: Ceratium candelabrum, 6: Ceratium fusus, 38: Protoperidinium diabolum, 34: Protoperidinium divergens, 20: Karenia selliformis, and 41: Pyrophacus sp., the diatoms 51: Climacosphenia sp., 47: Biddulphia sp., 54: Licmophora sp., 49: Coscinodiscus sp., 50: Chaetoceros sp., and 45: Amphora sp., and the cyanobacteria 71: Thalassiosira sp. Species associated with M (control station) were the dinoflagellates 9: Coolia monotis, 11: Diplopsalopsis sp., 21: Ostreopsis ovata, 22: Peridinium sp., 28: Prorocentrum lima, 31: Protoperidinium sp., 29: Prorocentrum triestinum and the diatoms 45: Asterionellopsis glacialis, 58: Navicula sp. Species whose coverage and frequency were less than $40 \%$ were eliminated.

station contrary to diatoms that were more abundant. Phytoplankton variation between control and disturbed conditions is similar to those found by Ben Brahim et al. [19] in the south of Tunisia (Gulf of Gabes), by Wang et al. [20] in Baiyangdian Lake (China), and by Davies and Ugwumba [21] in Okpoka Creek (Nigeria). In addition, some fertilization experiments have shown shifts in relative dominance among algal species, with a shift towards cyanobacteria [2] and diatoms [22] under nutrient enrichment.

The high species number in disturbed station reflects an enhanced nutrient enrichment, as reported in other studies with a high abundance of centric over pennate diatoms [23, 24]. The same observation was made in Lebanese coastal waters [25]. Indeed, Egge and Aksnes [26] and Fouillaron et al. [27] showed that diatoms always numerically dominated the phytoplankton community when silicic acid (DSi) concentrations were above $2 \mu \mathrm{M}$. Previous studies have shown that nutrient enrichment was associated with changes in species composition [1, 21, 28]. However, each microalgal group displayed a unique spatial pattern in response to $\mathrm{N}$ and $\mathrm{P}$ enrichment [2]. Our data showed that there is an increase of diatoms and cyanobacteria in disturbed station compared to control. For insistence, Anabaena sp. that was abundant in 
TABLE 3: ANOVA on microalgae abundances between controls and disturbed stations. M: Mahdia (control station); K: Skhira (disturbed station); n.s.: not significant.

\begin{tabular}{|c|c|c|c|c|c|}
\hline & DF & MS & $F$ & $P$ & Tukey's test \\
\hline \multicolumn{6}{|c|}{ Total abundance } \\
\hline Station & 1 & 781250 & 0.002 & 0.963 & n.s. \\
\hline Residuals & 17 & 356395368 & & & \\
\hline \multicolumn{6}{|c|}{ Species number } \\
\hline Station & 1 & 338 & 6.953 & 0.017943 & $\mathrm{~K}>\mathrm{M}$ \\
\hline Residuals & 17 & 48.61 & & & \\
\hline \multicolumn{6}{|l|}{$H^{\prime}$} \\
\hline Station & 1 & 0.25515 & 1.552 & 0.230796 & n.s. \\
\hline Residuals & 17 & 0.16442 & & & \\
\hline \multicolumn{6}{|c|}{ Dinoflagellates } \\
\hline Station & 1 & 504560556 & 5.662 & 0.029 & $\mathrm{~K}<\mathrm{M}$ \\
\hline Residuals & 17 & 89109085 & & & \\
\hline \multicolumn{6}{|l|}{ Gonyaulacales } \\
\hline Station & 1 & 297273472 & 12.488 & 0.003 & $\mathrm{~K}<\mathrm{M}$ \\
\hline Residuals & 17 & 23802884 & & & \\
\hline \multicolumn{6}{|c|}{ Gymnodiniales } \\
\hline Station & 1 & 6805.6 & 0.036 & 0.85 & n.s. \\
\hline Residuals & 17 & 185040.8 & & & \\
\hline Total & 18 & & & & \\
\hline \multicolumn{6}{|l|}{ Dinophysiales } \\
\hline Station & 1 & 80000 & 4 & 0.062 & n.s. \\
\hline Residuals & 17 & 20000 & & & \\
\hline \multicolumn{6}{|c|}{ Prorocentrales } \\
\hline Station & 1 & 40951250 & 6.177 & 0.024 & $\mathrm{~K}<\mathrm{M}$ \\
\hline Residuals & 17 & 6628897 & & & \\
\hline \multicolumn{6}{|l|}{ Peridiniales } \\
\hline Station & 1 & 1250 & 0.001 & 0.974 & n.s. \\
\hline Residuals & 17 & 1148603 & & & \\
\hline \multicolumn{6}{|l|}{ Diatoms } \\
\hline Station & 1 & $4.81 E+08$ & 16.398 & $>0.001$ & $\mathrm{~K}>\mathrm{M}$ \\
\hline Residuals & 17 & $2.93 E+07$ & & & \\
\hline \multicolumn{6}{|c|}{ Pennate diatoms } \\
\hline Station & 1 & 48840139 & 0.924 & 0.35 & n.s. \\
\hline Residuals & 17 & 52850433 & & & \\
\hline \multicolumn{6}{|c|}{ Centric diatoms } \\
\hline Station & 1 & 196020000 & 7.158 & 0.016 & $\mathrm{M}<\mathrm{K}$ \\
\hline Residuals & 17 & 27384118 & & & \\
\hline \multicolumn{6}{|l|}{ Cyanobacteria } \\
\hline Station & 1 & 533889 & 12.613 & 0.002 & $\mathrm{~K}>\mathrm{M}$ \\
\hline Residuals & 17 & 42326 & & & \\
\hline
\end{tabular}

Skhira station (Table 3 ) is pollution indicator species usually associated with eutrophic water bodies [29] and has been recorded in Okpoka Creek (Niger) due to the increased influx of nutrients from anthropogenic inputs [21].

Phytoplankton species respond in different ways to nutrient enrichment, probably based on their life cycle characteristics, such as growth rate and their absorptive capacity [30]. According to Lepoint et al. [31], it is difficult to predict which group would be favored by the moderate intake of nutrients. For example, Lin et al. [32] found that nutrient enrichment $\left(\mathrm{NO}_{3}{ }^{-}, \mathrm{NH}_{4}{ }^{+}\right.$, and $\mathrm{PO}_{4}{ }^{-}$, either alone or in combination) did not result in an increase in the abundance of phytoplankton. These communities respond in complex ways to the addition of nutrients. The seasonal influence on the response of microalgae to nutrient enrichment seems important [33].

Our results showed that $\mathrm{Si}(\mathrm{OH})_{4}$ and nitrogen $\left(\mathrm{NH}_{4}{ }^{+}\right.$, NT) are factors that contribute to differences of species abundance between stations (CCA; Figure 3). Indeed, silicon (Si) played the most important role in the growth and development of diatoms while dinoflagellates were mostly controlled by phosphorus (P) availability [34, this study]. When phosphorus loading increased, a shift from diatoms to dinoflagellates was observed [35]. Krumme and Liang [36] and Wear et al. [28] have found that diatoms were high in terms of abundance and species composition in nutrient enrichment station. Pennate and centric diatoms respond differently to disturbance. Indeed, our results showed that centric diatoms were higher in disturbed station, result found also by Harrison et al. [37]. Indeed, diatoms have the capacity of rapid cell division with growth rates (up to 5.9 day $^{-1}$ ) generally much higher than those for dinoflagellates (up to 2.7 day $^{-1}$ ) based on equivalent body mass [38].

The canonical molar Redfield ratio of $16: 1(\mathrm{~N}: \mathrm{P})$ in the water column has traditionally been considered the determining factor for whether there is potential for $\mathrm{N}$ - or $\mathrm{P}$ limitation in phytoplankton for a specific ecosystem $[39,40]$. If the ratio of dissolved inorganic $\mathrm{N}$ (DIN) compared to dissolved inorganic $\mathrm{P}$ (DIP) is greater than $16: 1$ and nutrients are limiting, the system is considered P-limited [41]. Our data allow us to highlight that disturbed station was characterized by a slight P-limitation, which is known to induce the synthesis of alkaline phosphatases, AP, for numerous phytoplankton species such as Alexandrium catenella [42], Ptychodiscus brevis [43], Karenia mikimotoi [44], Gymnodinium catenatum, and Alexandrium tamarense [45]. AP is an enzyme used to convert DOP (dissolved organic P) to bioavailable DIP (dissolved inorganic $\mathrm{P}$ ) by cleaving $\mathrm{P}$ from the DOP molecule $[42,46]$. Some diatoms also do produce AP, including Pseudo-nitzschia, Chaetoceros, and Skeletonema $[41,47]$. But previous studies [41, 47] have indicated that some phytoplankton groups (dinoflagellates and coccolithophores) may have a greater P-requirement and utilize DOP more readily than diatoms through the production of AP.

We also found a strong Si-limitation in the control station which seems to be the main driver of differences in diatoms' assemblages between control and disturbed conditions. This station showed low abundance of diatoms (Figure 4, Table 4) compared to disturbed station. This result was also found by previous study $[1,21,34,35]$ that showed that increase in the $\mathrm{N}$ : Si ratio was proportional with the increase in flagellates and the decrease of diatoms abundance [1].

Differences in species abundance and composition between the two stations cannot be assigned only to nutrients enrichment; many other factors could influence their distributions, such as water motion [1], light intensity [2], and pollution by heavy metals. For instance, in Skhira station (K), 
TABLE 4: SIMPER results.

\begin{tabular}{|c|c|c|c|c|c|c|}
\hline Species & $\begin{array}{c}\text { Group K (disturbed station) } \\
\text { Av. abund. }\end{array}$ & $\begin{array}{c}\text { Group } \mathrm{M} \text { (control station) } \\
\text { Av. abund. }\end{array}$ & Av. Diss. & Diss./SD & Contrib.\% & Cum.\% \\
\hline Coscinodiscus sp. & 5566.67 & 0 & 15.47 & 1.14 & 17.93 & 17.93 \\
\hline Ostreopsis ovata & 33.33 & 4566.67 & 13.93 & 3.89 & 16.14 & 34.07 \\
\hline Coolia monotis & 0 & 3844.44 & 11.4 & 1.98 & 13.21 & 47.28 \\
\hline Prorocentrum lima & 77.78 & 3666.67 & 10.88 & 2.11 & 12.61 & 59.88 \\
\hline Nitzshoides sp. & 2416.67 & 0 & 5.35 & 0.46 & 6.19 & 66.08 \\
\hline Nitzschia sp. & 933.33 & 122.22 & 2.58 & 1.26 & 2.99 & 69.07 \\
\hline Navicula sp. & 1633.33 & 1444.44 & 2.48 & 1.38 & 2.88 & 71.95 \\
\hline Pleurosigma sp. & 300 & 838.89 & 1.97 & 1.15 & 2.28 & 74.24 \\
\hline Peridinium sp. & 133.33 & 538.89 & 1.49 & 1.29 & 1.72 & 77.72 \\
\hline Pinnularia sp. & 55.56 & 483.33 & 1.38 & 1.61 & 1.6 & 79.32 \\
\hline Prorocentrum rathymum & 477.78 & 0 & 1.28 & 1.34 & 1.48 & 80.8 \\
\hline Karenia selliformis & 400 & 0 & 0.91 & 0.52 & 1.06 & 81.86 \\
\hline Polykrikos sp. & 255.56 & 338.89 & 0.9 & 1.45 & 1.05 & 82.91 \\
\hline Licmophora sp. & 311.11 & 0 & 0.89 & 1.49 & 1.03 & 83.93 \\
\hline Chaetoceros sp. & 244.44 & 0 & 0.75 & 0.62 & 0.87 & 84.8 \\
\hline Anabaena sp. & 288.89 & 116.67 & 0.64 & 1.43 & 0.75 & 85.55 \\
\hline Protoperidinium sp. & 88.89 & 150 & 0.57 & 1.28 & 0.66 & 86.93 \\
\hline Gyrodinium sp. & 111.11 & 61.11 & 0.54 & 0.56 & 0.62 & 87.56 \\
\hline Biddulphia sp. & 166.67 & 0 & 0.51 & 0.58 & 0.59 & 88.15 \\
\hline Striatella unipunctata & 200 & 0 & 0.49 & 0.88 & 0.57 & 88.72 \\
\hline Thalassiosira sp. & 166.67 & 0 & 0.45 & 0.88 & 0.52 & 89.23 \\
\hline Leptocylindrus sp. & 133.33 & 0 & 0.42 & 0.57 & 0.49 & 89.72 \\
\hline Scrippsiella sp. & 133.33 & 0 & 0.41 & 0.71 & 0.48 & 90.2 \\
\hline
\end{tabular}

TABle 5: CCA results.

\begin{tabular}{|c|c|c|c|c|}
\hline & \multicolumn{2}{|c|}{ Using environmental variables } & \multicolumn{2}{|c|}{ Using nutrient ratios } \\
\hline & Axis 1 & Axis 2 & Axis 1 & Axis 2 \\
\hline Eigenvalues & 0.493 & 0.154 & 0.153 & 0.104 \\
\hline Species-environment correlations & 0.994 & 0.943 & 0.975 & 0.935 \\
\hline Cumulative percentage variance of species data & 29.7 & 38.9 & 38.8 & 45.2 \\
\hline Cumulative percentage variance of species-environment relation & 36.2 & 47.5 & 85.8 & 100.0 \\
\hline Sum of all eigenvalues & \multicolumn{2}{|c|}{1.662} & \multicolumn{2}{|c|}{1.623} \\
\hline Sum of all canonical eigenvalues & \multicolumn{2}{|c|}{1.361} & \multicolumn{2}{|c|}{0.734} \\
\hline Explained variance by CCA & \multicolumn{2}{|c|}{$81.88 \%$} & \multicolumn{2}{|c|}{$45.22 \%$} \\
\hline \multicolumn{5}{|l|}{ Intraset correlations of variables with axes } \\
\hline $\mathrm{NO}_{2}^{-}$ & -0.135 & -0.450 & & \\
\hline $\mathrm{Si}(\mathrm{OH})_{4}$ & -0.955 & -0.026 & & \\
\hline $\mathrm{NO}_{3}^{-}$ & 0.281 & -0.339 & & \\
\hline $\mathrm{NH}_{4}^{+}$ & -0.613 & -0.445 & & \\
\hline $\mathrm{PO}_{4}^{3-}$ & 0.832 & -0.060 & & \\
\hline NT & -0.588 & -0.384 & & \\
\hline PT & 0.145 & 0.210 & & \\
\hline$T$ & -0.879 & -0.072 & & \\
\hline Salinity & -0.386 & 0.143 & & \\
\hline $\mathrm{pH}$ & -0.821 & 0.033 & & \\
\hline SM & -0.497 & -0.411 & & \\
\hline $\mathrm{N}: \mathrm{P}$ & & & 0.7204 & 0.6059 \\
\hline Si $: N$ & & & 0.7606 & -0.3145 \\
\hline $\mathrm{Si}: \mathrm{P}$ & & & 0.8765 & 0.2950 \\
\hline
\end{tabular}


there is phosphate treatments factory that contaminates water and sediments by cadmium, mercury, arsenic, and so forth, as reported by Smaoui-Damak et al. [6].

The phytoplankton-grazer interaction also plays an important role in controlling abundance and diversity of microalgae. Indeed, plankton is a food source for a range of grazers which influence their diversity and their abundance [48].

The present study underlines the use of phytoplankton assemblages as general indicators of anthropogenic disturbance in marine ecosystems. It was clear that the effect of nutrient loading and turbidity could be depicted in the community structure and diversities of phytoplankton. During period of study (August), nutrient enrichment (mainly $\mathrm{Si}(\mathrm{OH})_{4}$ and $\mathrm{NH}_{4}^{+}$) and turbidity were associated with increase of diatoms and cyanobacteria and decrease of dinoflagellates abundance, especially Gonyaulacales and Prorocentrales. The existence of Si- and P-limitation in study sites seems to be the main driver of differences in phytoplankton assemblages between control and disturbed conditions.

\section{Appendix}

See Table 2.

\section{Conflict of Interests}

The authors declare that there is no conflict of interests regarding the publication of this paper.

\section{Acknowledgments}

The authors wish to acknowledge use of the Maptool program for analysis and graphics in this paper. They thank Dr. Idriss and Ahmed Omar Mabrouk and Groupe Chimique Tunisien (CGT, Skhira factory) for essential help. They also thank Professor Robert A. Patzner and the reviewer for his comments which improved the quality of the paper. In addition, they thank all the team of the Journal of Marine Biology for their professionalism and rapid response.

\section{References}

[1] T. J. Smayda, D. G. Borkman, G. Beaugrand, and A. G. Belgrano, "Ecological effects of climate variation in the North Atlantic: phytoplankton," in Ecological Effects of Climate Variations in the North Atlantic, N. C. Stenseth, G. Ottersen, J. Hurrell, and A. Belgrano, Eds., Oxford University Press, 2004.

[2] A. R. Armitage, T. A. Frankovich, and J. W. Fourqurean, "Variable responses within epiphytic and benthic microalgal communities to nutrient enrichment," Hydrobiologia, vol. 569, no. 1, pp. 423-435, 2006.

[3] A. R. Price, "The marine food chain in relation to biodiversity," TheScientificWorldJournal, vol. 1, pp. 579-587, 2001.

[4] F. Gómez and G. Gorsky, "Annual microplankton cycles in Villefranche Bay, Ligurian Sea, NW Mediterranean," Journal of Plankton Research, vol. 25, no. 4, pp. 323-339, 2003.
[5] A. J. Underwood, "Beyond BACI: the detection of environmental impacts on populations in the real, but variable, world," Journal of Experimental Marine Biology and Ecology, vol. 161, no. 2, pp. 145-178, 1992.

[6] W. Smaoui-Damak, A. Hamza-Chaffai, B. Berthet, and J. C. Amiard, "Preliminary study of the clam Ruditapes decussatus exposed in situ to metal contamination and originating from the gulf of Gabes, Tunisia," The Bulletin of Environmental Contamination and Toxicology, vol. 71, no. 5, pp. 961-970, 2003.

[7] M. Ben Brahim, A. Hamza, I. Hannachi et al., "Variability in the structure of epiphytic assemblages of Posidonia oceanica in relation to human interferences in the Gulf of Gabes, Tunisia," Marine Environmental Research, vol. 70, no. 5, pp. 411-421, 2010.

[8] A. Hattour, K. Ben Mustapha, A. El Abed, and M. Chaouch, "L'écosystème du golfe de Gabès; dégradation de son couvert végétal et de sa pêcherie benthique," Bulletins de l'Institut Océanographique et de Pêche de Salammbô, vol. 25, pp. 5-40, 1998.

[9] K. Ben Mustapha, "The Gulf of Gabes: a case study in the Mediterranean decline in fishing out the Mediterranean," in Proceedings of the 21st Session of the General Fisheries Commission for the Mediterranean (GFCM '95), Greenpeace International, Ed., pp. 8-9, The Netherlands, 1995.

[10] K. Grasshoff, M. Ehrhardt, and K. Kremling, Methods of Seawater Analysis, Chemie GmbH, Weinheim, Germany, 1983.

[11] D. M. Moore and R. C. Reynolds, X-Ray Diflraction and The Identification and Analysis of Clay Minerals, Oxford University Press, Oxford, UK, 1989.

[12] H. Utermohl, "Zur vervollkommung der quantitativen Phytomicroorganisms-Methodik," Mitteilungen der Internationalen Vereinigung für Theoretische und Angewandte Limnologie, vol. 9, pp. 1-38, 1958.

[13] L. Mabrouk, A. Hamza, and M. N. Bradai, "Variability in the structure of planktonic microalgae assemblages in water column associated with Posidonia oceanica (L.) bed in Tunisia," Journal of Marine Biology, vol. 2014, Article ID 621238, 7 pages, 2014.

[14] J. H. Zar, Biostatistical Analysis, Prentice Hall, Upper Saddle River, NJ, USA, 4th edition, 1999.

[15] P. J. Somerfield, K. R. Clarke, and F. Olsgard, "A comparison of the power of categorical and correlational tests applied to community ecology data from gradient studies," Journal of Animal Ecology, vol. 71, no. 4, pp. 581-593, 2002.

[16] K. R. Clarke and R. M. Warwick, Change in Marine Communities: An Approach to Statistical Analysis and Interpretation, PRIMER-E, Plymouth, UK, 2001.

[17] K. R. Clarke, "Non-parametric multivariate analyses of changes in community structure," Australian Journal of Ecology, vol. 18, no. 1, pp. 117-143, 1993.

[18] C. J. F. ter Braak and P. F. M. Verdonschot, "Canonical correspondence analysis and related multivariate methods in aquatic ecology," Aquatic Sciences, vol. 57, no. 3, pp. 255-289, 1995.

[19] M. Ben Brahim, A. Hamza, S. Ben Ismail, L. Mabrouk, A. Bouain, and L. Alaya, "What factors drive seasonal variation of phytoplankton, protozoans and metazoans on leaves of Posidonia oceanica and in the water column along the coast of the Kerkennah Islands, Tunisia?" Marine Pollution Bulletin, vol. 71, no. 1-2, pp. 286-298, 2013.

[20] X. Wang, Y. Wang, L. Liu, J. Shu, Y. Zhu, and J. Zhou, "Phytoplankton and eutrophication degree assessment of Baiyangdian Lake Wetland, China," The Scientific World Journal, vol. 2013, Article ID 436965, 8 pages, 2013. 
[21] O. A. Davies and O. A. Ugwumba, "Tidal influence on nutrients status and phytoplankton population of Okpoka Creek, Upper Bonny Estuary, Nigeria," Journal of Marine Biology, vol. 2013, Article ID 684739, 16 pages, 2013.

[22] T. A. Frankovich, A. R. Armitage, A. H. Wachnicka, E. E. Gaiser, and J. W. Fourqurean, "Nutrient effects on seagrass epiphyte community structure in florida bay," Journal of Phycology, vol. 45, no. 5, pp. 1010-1020, 2009.

[23] X. N. Verlecar, S. R. Desai, A. Sarkar, and S. G. Dalal, "Biological indicators in relation to coastal pollution along Karnataka Coast, India," Water Research, vol. 40, no. 17, pp. 3304-3312, 2006.

[24] K. P. Raveesha, A. Mohan, N. Chethan, R. J. Katti, and H. R. V. Reddy, "Community structure of net phytoplankton along surf zone of Mangalore during southwest monsoon season," Indian Journal of Marine Sciences, vol. 39, no. 3, pp. 445-448, 2010.

[25] M. Abboud Abi Saab, M. Fakhri, M. T. Kassab, and N. Matar, "Phénomène exceptionnel d'eaux colorées au printemps dans la zone côtière Libanaise de Zouk-Nahr El Kelb," Lebanese Science Journal, vol. 9, pp. 61-70, 2007.

[26] J. K. Egge and D. L. Aksnes, "Silicate as regulating nutrient in phytoplankton competition," Marine Ecology Progress Series, vol. 83, no. 2-3, pp. 281-289, 1992.

[27] P. Fouillaron, P. Claquin, S. L'Helguen et al., "Response of a phytoplankton community to increased nutrient inputs: a mesocosm experiment in the Bay of Brest (France)," Journal of Experimental Marine Biology and Ecology, vol. 351, no. 1-2, pp. 188-198, 2007.

[28] D. J. Wear, M. J. Sullivan, A. D. Moore, and D. F. Millie, "Effects of water-column enrichment on the production dynamics of three seagrass species and their epiphytic algae," Marine Ecology Progress Series, vol. 179, pp. 201-213, 1999.

[29] D. I. Nwankwo, "Seasonal changes in phytoplankton composition and diversity in the Epe lagoon, Nigeria," Acta Hydrobiology, vol. 40, no. 2, pp. 83-92, 1998.

[30] C. J. M. Philippart, G. C. Cadée, W. Van Raaphorst, and R. Riegman, "Long-term phytoplankton-nutrient interactions in a shallow coastal sea: algal community structure, nutrient budgets, and denitrification potential," Limnology and Oceanography, vol. 45, no. 1, pp. 131-144, 2000.

[31] G. Lepoint, J. Jacquemart, J.-M. Bouquegneau, V. Demoulin, and S. Gobert, "Field measurements of inorganic nitrogen uptake by epiflora components of the seagrass Posidonia oceanica (Monocotyledons, Posidoniaceae)," Journal of Phycology, vol. 43, no. 2, pp. 208-218, 2007.

[32] H.-J. Lin, S. W. Nixon, D. I. Taylor, S. L. Granger, and B. A. Buckley, "Responses of epiphytes on eelgrass, Zostera marina L., to separate and combined nitrogen and phosphorus enrichment," Aquatic Botany, vol. 52, no. 4, pp. 243-258, 1996.

[33] H. A. Neckles, "The role of epiphytes in seagrass production and survival: microcosm studies and simulation modelling," in Proceedings and Conclusions of Workshops on: Submerged Aquatic Vegetation and Photosynthetically Active Radiation, L. J. Morris and D. A. Tomasko, Eds., Special Publication St Johns River Water Management District, Palatka, Fla, USA, 1993.

[34] M. A. Chikhaoui, A. S. Hlaili, and H. H. Mabrouk, "Seasonal phytoplankton responses to N:Si:P enrichment ratio in the Bizerte Lagoon (southwestern Mediterranean)," Comptes RendusBiologies, vol. 331, no. 5, pp. 389-408, 2008.

[35] I. J. Hodgkiss, "The N:P ratio revisited," in Prevention and Management of Harmful Algal Blooms in the South China Sea,
K. C. Ho and Z. D. Wang, Eds., pp. 344-355, School of Science and Technology, The Open University of Hong Kong, 2001.

[36] U. Krumme and T.-H. Liang, "Tidal-induced changes in a copepod-dominated zooplankton community in a macrotidal mangrove channel in northern Brazil," Zoological Studies, vol. 43, no. 2, pp. 404-414, 2004.

[37] P. J. Harrison, P. J. Clifored, W. P. Cochlan et al., "Nutrient and plankton dynamics in the Fraser River plume, Strait of Georgia, British Columbia," Marine Ecology Progress Series, vol. 70, no. 3, pp. 291-304, 1991.

[38] T. J. Smayda, "Harmful algal blooms: their ecophysiology and general relevance to phytoplankton blooms in the sea," Limnology and Oceanography, vol. 42, no. 5, pp. 1137-1153, 1997.

[39] A. C. Redfield, "The biological control of chemical factors in the environment," American Scientist, vol. 46, no. 3, pp. 205-221, 1958.

[40] J. Beardall, E. Young, and S. Roberts, "Approaches for determining phytoplankton nutrient limitation," Aquatic Sciences, vol. 63, no. 1, pp. 44-69, 2001.

[41] D. Nicholson, S. Dyhrman, F. Chavez, and A. Paytan, "Alkaline phosphatase activity in the phytoplankton communities of Monterey Bay and San Francisco Bay," Limnology and Oceanography, vol. 51, no. 2, pp. 874-883, 2006.

[42] C. Jauzein, C. Labry, A. Youenou, J. Quéré, D. Delmas, and Y. Collos, "Growth and phosphorus uptake by the toxic dinoflagellate Alexandrium catenella (dinophyceae) in response to phosphate limitation," Journal of Phycology, vol. 46, no. 5, pp. 926-936, 2010.

[43] G. A. Vargo and E. Shanley, "Alkaline phosphatase activity in the red-tide dinoflagellate, Ptychodiscus brevis," Marine Ecology, vol. 6, no. 3, pp. 251-264, 1985.

[44] H. Yamaguchi, H. Sakou, K. Fukami, M. Adachi, M. Yamaguchi, and T. Nishijima, "Utilization of organic phosphorus and production of alkaline phosphatase by the marine phytoplankton, Heterocapsa circularisquama, Fibrocapsa japonica and Chaetoceros ceratosporum," Plankton Biology and Ecology, vol. 52, no. 2, pp. 67-75, 2005.

[45] J. O. Seok, T. Yamamoto, Y. Kataoka, O. Matsuda, Y. Matsuyama, and Y. Kotani, "Utilization of dissolved organic phosphorus by the two toxic dinoflagellates, Alexandrium tamarense and Gymnodinium catenatum (Dinophyceae)," Fisheries Science, vol. 68, no. 2, pp. 416-424, 2002.

[46] A. D. Cembella, N. J. Antia, and P. J. Harrison, "The utilization of inorganic and organic phosphorus compounds as nutrients by eukaryotic microalgae: a multidisciplinary perspective. Part 2," Critical Reviews in Microbiology, vol. 11, no. 1, pp. 13-81, 1984.

[47] M. B. Peacock and R. M. Kudela, "A method for determining alkaline phosphatase activity in marine phytoplankton using spectrofluorometry," Journal of Microbiological Methods, vol. 89, no. 3, pp. 209-212, 2012.

[48] O. Sarnelle, K. W. Kratz, and S. D. Cooper, "Effects of an invertebrate grazer on the spatial arrangement of a benthic microhabitat," Oecologia, vol. 96, no. 2, pp. 208-218, 1993. 

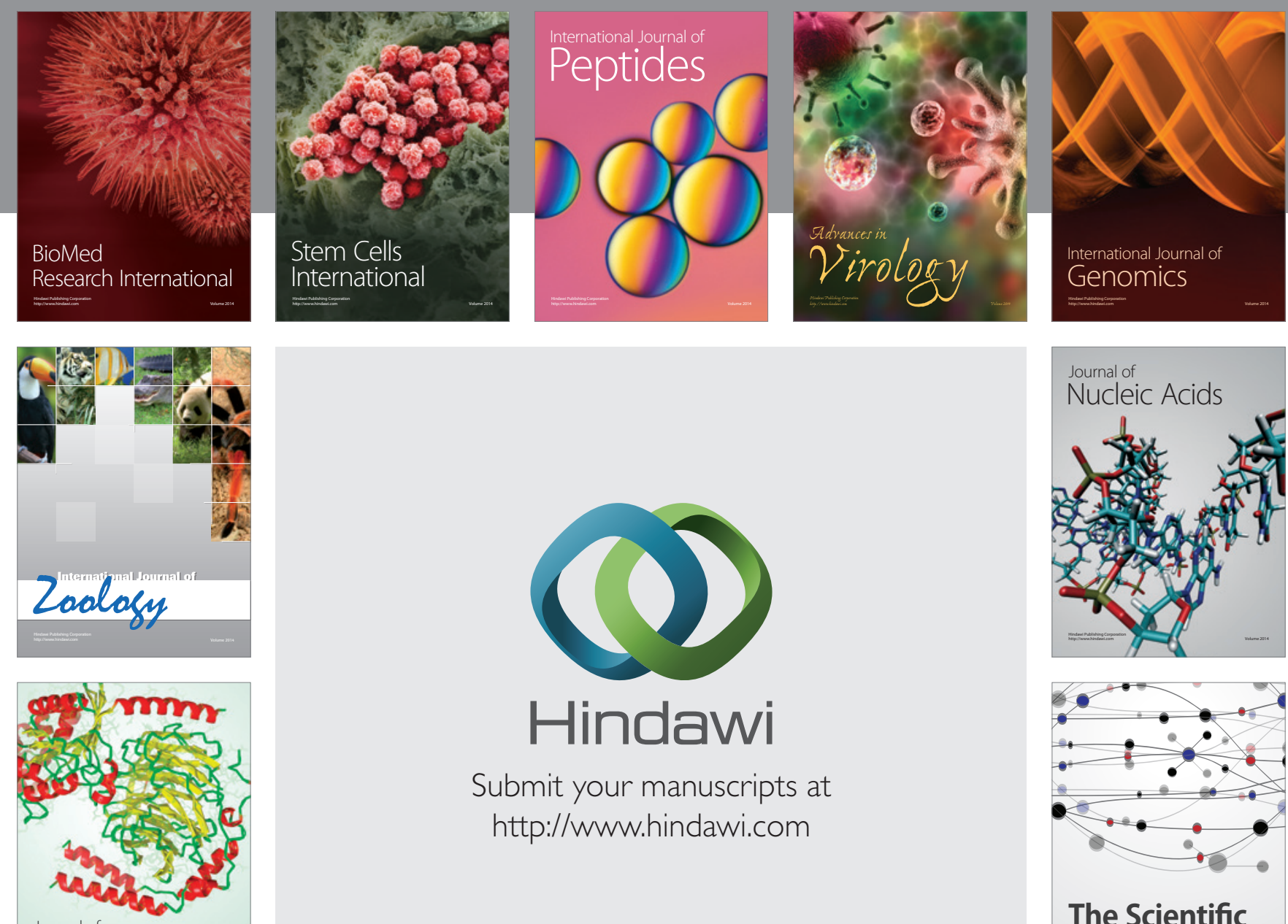

Submit your manuscripts at

http://www.hindawi.com

Journal of
Signal Transduction
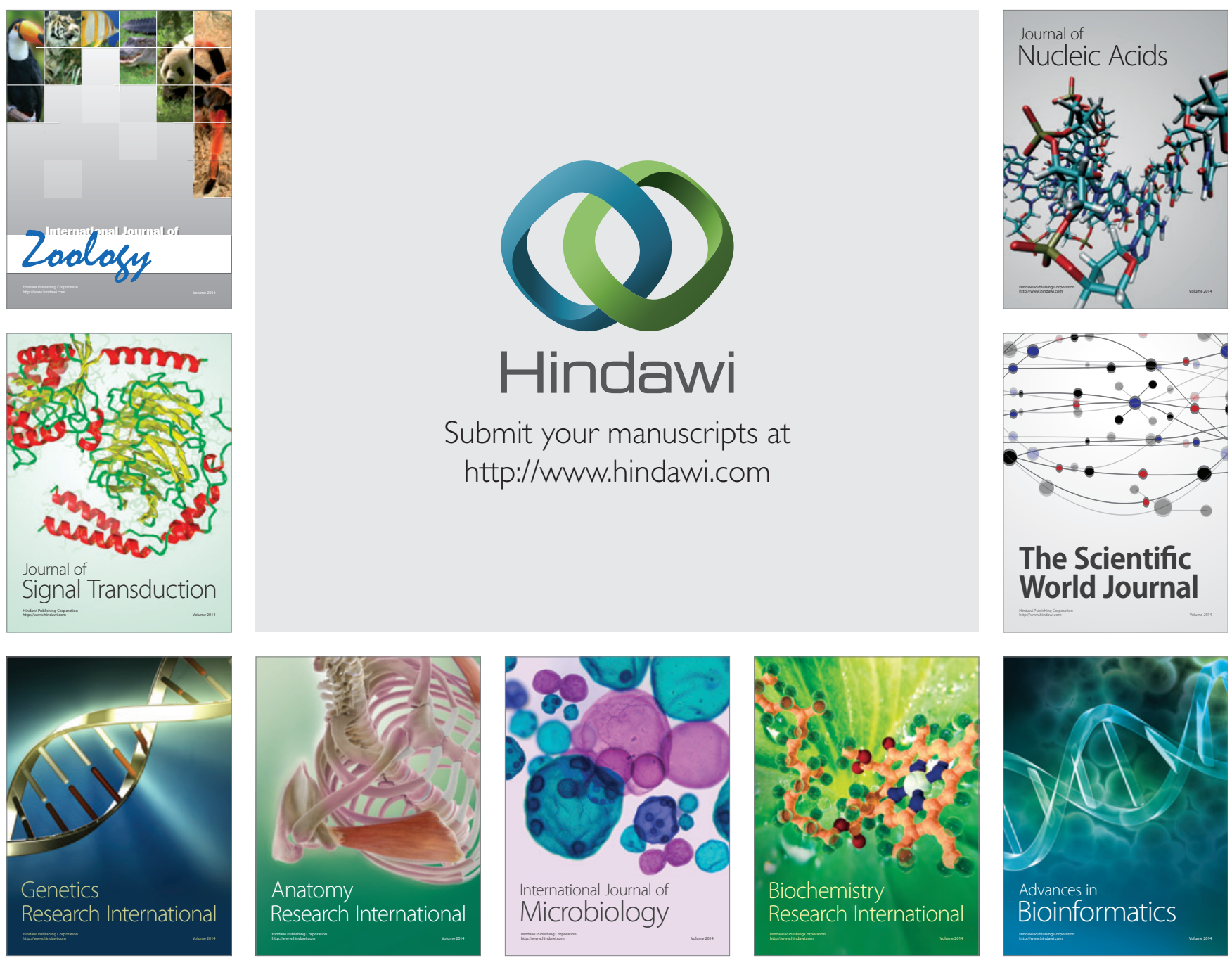

The Scientific World Journal
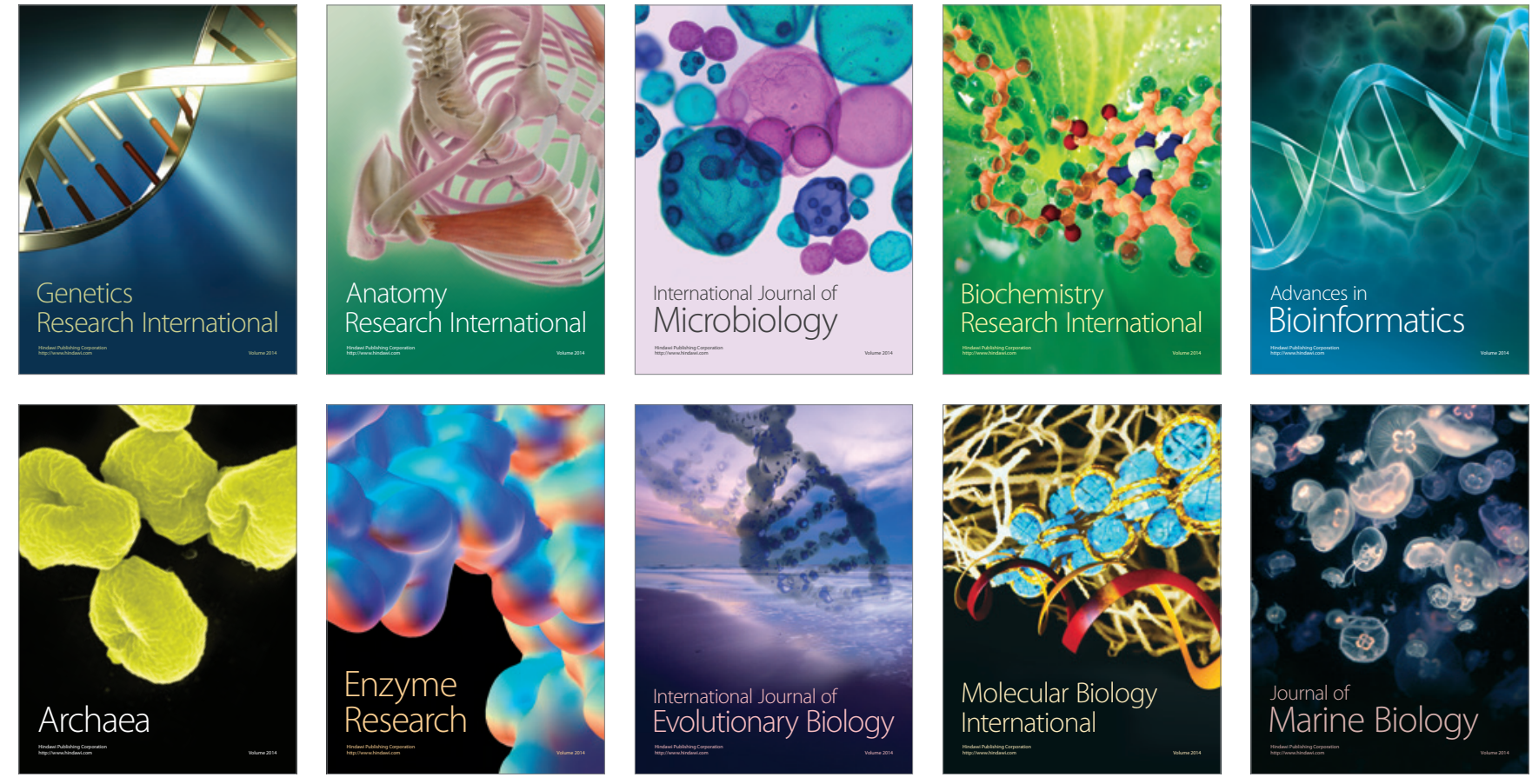